РОЗДІЛ ІІІ. ПРОБЛЕМИ ЗАГАЛЬНОї ПЕДАГОГІКИ

UDC 37.018 .26

\author{
Olga Zamecka-Zalas \\ Jan Kochanowski University of Kielce \\ University Branch in Piotrków Trybunalski, Poland \\ ORCID ID 0000-0002-3005-3125 \\ Izabela Kiełtyk-Zaborowska \\ Jan Kochanowski University of Kielce \\ University Branch in Piotrków Trybunalski, Poland \\ ORCID ID 0000-0003-4120-6446 \\ DOI 10.24139/2312-5993/2020.05-06/161-178
}

\title{
THE ROLE OF PARENTS AND THE COOPERATION WITH SCHOOL IN PREVENTING AND OVERCOMING EDUCATIONAL PROBLEMS
}

The article presents an empirical study on the role of parents and their cooperation with schools in preventing and overcoming educational difficulties.

To teach effectively it is not enough to be competent and friendly towards pupils. Educational difficulties are the result of many elements, so a teacher has a limited power to solve such problems. Even most perfect educational methods used by a teacher who is lonely in his acting or by parents acting alone will not be effective. They have to cooperate and support each other to prevent difficulties. That is why the cooperation of parents with school is indispensable in order to deal with difficult behavior of pupils.

Key words cooperation of parents with school, educational difficulties of early school children.

Introduction. Family and school are two environments which have the greatest influence on children both by forming role models assimilated by children through the process of imitation and identification and by creating appropriate conditions for broad development (Szymański, 2013, p. 114-124). The fate of children, development of their interests and abilities depends on their parents and teachers. Therefore, they should work together for the good of the child. It is thanks to the parents that a teacher can understand the child and their problems better. Parents can support the didactic and educational work of the teacher by motivating the child for systematic work, helping them in overcoming difficulties and forming a positive attitude towards learning, teachers and school (Babiuch, 2002, p. 7; Zamecka-Zalas, 2011, p. 138). Thus, cooperation of school with parents and guardians in fighting against difficult behaviour of pupils is advisable. Parents in school are not supplicants squeezed in an undersized desk. If they are to be aware and responsible for their children's development, they have to feel the teachers consider them to be partners and will hear them out gladly and begin to 
cooperate (Zamecka-Zalas, 2014, p. 25). The school's cooperation with the child's home function on the basis of partnership and subjectivity of all partners involved in this cooperation. According to Józefa Bałachowicz (2009, p. 173), subjectivity is what defines man and what defines his relations in the world. Therefore, shaping the subjective existence of a young person and supporting his development is the basis of education.

Analysis of relevant research. There is research in progress into the subject matter undertaken herein, including studies by the following scholars: C. Hillenbrand (2007), A. Kołakowski (2014), M. Babiuch (2002), N. Havers (1978), A. Sakowicz-Boboryko (2004), K. Oleksa (2016), A. Nadolska (2013), M. Mendel (2009), J. E. Epstein (1995), H. Spionek (1985), O. Zamecka-Zalas (2014), I. Kiettyk-Zaborowska (2016).

The aim of the article. For the purposes of this article, research has been conducted concerning the role of parents and their cooperation with school in preventing and overcoming educational problems. The theoretical and cognitive objective of this research concerned the areas and forms of cooperation between parents and teachers in preventing and overcoming educational problems in early school children.

Research methods. The practical implementation objective was to process the conclusions and opinions from parents about the support they get from school in the didactic and educational process of their children. The method of diagnostic survey was used in the research.

\section{Research results.}

\section{The concept of educational problems}

The term educational difficulties has a wide range of meaning. Currently, it is used interchangeably or simultaneously with the terms: "conduct disorder" and "social maladjustment".

The term educational problems assumes that the child can be treated only as the perpetrator and not as a subject who experiences the difficulties. We do not say that children experience educational problems but rather that they cause them. When discussing educational problems caused by pupils, it is necessary to explain the term 'conduct disorder', since it is used in literature in many meanings and scopes (Hillenbrand, 2007, p. 21). The concept of educational difficulties is understood as a student's offense against the rules of behavior, noticed by the teacher and assessed by him as disruptive and inappropriate (Havers, 1978, p. 21). Norbert Havers draws attention to the fact that every upbringing difficulty can be called a behavior disorder, but not every 
behavior disorder is an upbringing difficulty. Behavior disorder is therefore a superior concept over educational difficulties.

Behavior disorder is therefore a superior concept over educational difficulties (Havers, 1978, p. 24). According to Clemens Hillenbrand, behavioral disorders include problems studied by various disciplines associated with pedagogy: psychology, sociology, medicine, and law (Hillenbrand, 2007, p. 22). The so-called difficult behaviours in children cover an entire range of actions which make it difficult to communicate with them and maintain discipline, interfere with the others' right to learn and interrupt classes, are dangerous mentally and physically for both the disturber and the other pupils. In the case of older classes, difficult behaviours follow certain patterns but in grades 1-3 they most frequently occur as unpredictable situations, which are hard to classify. A problem could manifest itself in the form of aggression towards others, destruction of property, mocking the teacher, disturbing classes, mouthing off etc. Educational problems are often related to learning difficulties. Difficult behaviours of pupils make it impossible to conduct classes effectively. Therefore, it is important to recognise the causes of educational problems in order to be able to counteract them. For this, it is necessary to cooperate with parents and guardians of children.

\section{Causes of educational problems}

Katarzyna Oleksa lists the following causes of educational problems: biological, personality and situational. Biological factors concerning various somatic characteristics of the organism are related to psychological factors.

Biological causes include neurological changes - functional disturbances of the pupil's sympathetic or parasympathetic system, which manifest themselves in hyperactivity, impulsiveness and concentration disorders. Neurological disorders may lead to disturbances in the child's development in the motor, cognitive and emotional spheres. Symptoms of disorders in the motor sphere include inability to remain motionless for as little as several minutes, frequent leg swinging, sudden standing up, fidgeting in the seat, walking aimlessly around the classroom, increased fine motor activity - finger tapping, fidgeting with objects, nodding, mouth movements etc. Disorders in the cognitive sphere may show in considerable difficulty in concentrating, fast tiring, abandoning commenced activities, inability to organise work and to plan actions, messy handwriting, articulation problems etc. Anomalies in the emotional sphere may be characterised by impulsive behaviour, such as throwing objects, provoking classmates, inability to control strong emotions, going into a frenzy, aggressive behaviours, etc. (Oleksa, 2016, p. 19). 
Personality-related causes of difficult behaviours include mainly temperament types. Temperament is a set of genetically determined features which manifest themselves from an early age. Jan Strelau distinguished six main dimensions of temperament:

Activity - i.e. the need for high stimulation, emotional reactivity - shows in intense response to stimuli, sensitivity - shows in strong response, even if the stimulus has low sensory value, endurance - ability to act under the influence of stimuli for a long time, briskness - tendency to respond quickly, to maintain a high rate of activity and easy response change, perseveration - the pupil tends to continue an activity even after the stimulus has ceased (Oleksa, 2016, p. 20).

Disorders in the cognitive, emotional, intellectual and physical spheres are often the source of a child's school failures (Sakowicz-Boboryko, 2004, p. 32).

Social conditions constitute another group of factors. The primary environment of a child's life is the family, but it does not always convey socially acceptable values. Excessive control or lack of interest may contribute to the development of emotional disorders in a child (Sakowicz-Boboryko, 2004, p. 32).

Situational causes are stimuli which result from different responses, e.g. in class - arguments between pupils, aggression, anger resulting from getting worse grades, at home - divorce of the parents, arguments, domestic violence, illness of the parents etc. (Oleksa, 2016, p. 20).. Sometimes the situation which triggers impulsiveness, anger or aggression is related to school and sometimes it is not. The cause of inappropriate behaviour of pupils can be a difficult situation at home.

\section{Overcoming educational problems and cooperation with parents}

In overcoming educational problems, it is necessary to cooperate with parents, talk to them and establish a common front of action. Determining the causes of educational problems and eliminating factors which lie outside school may improve the pupil's behaviour.

Effective cooperation with parents is conditioned by an open attitude of the teacher and rejection of any judgement and prejudice. The teacher should be the source of information on what should be done and how to assist parents in overcoming the problems. The parents must be informed that a very important element is to talk with the children and to dedicate them free time during the day. In addition, introducing a proper daily schedule, setting time for fun, learning and eating gives the children a sense of security and teaches them to operate within a certain framework (Oleksa, 2016, p. 26-17). Cooperation between parents and teachers is more and more frequently based on the "method of family tutoring", which comes down to assigning the child and the parents a tutor. The tutor's role is to provide support to the pupil, to offer 
instructions which will help them overcome the difficulties they may face. The tutor and the parents prepare an education plan, which should be implemented both at school and at home. Thus, close cooperation between the parents and the teacher will favour creating the right educational situation, commencing action aimed at supporting both parties in overcoming the difficulties that occur (Skupień \& Kowal, 2019, p. 12-14).

In building a relation with the parent, an important element is to initially prepare an appropriate space in the institution, to carefully plan meetings/consultations. Correct mutual relationship between the parent and the teacher will certainly facilitate taking correct steps in the case of problems and establishing a plan of action which will support the child/pupil and the parents in overcoming the difficulties (Leśniewska, 2019, p. 29-31).

One of the ways of coping with children's difficulties is art therapy, i.e. therapy through art, which helps to relieve strong emotions and facilitates the change of attitudes and behavior (Nadolska, 2013, p. 35). Such therapy may include contact with literature.

When children enter a new school or peer environment, sometimes struggling with traumatic situations at home, at various stages of their lives they face problems whose understanding requires above all time, acceptance and often some help from the adults. Using a book in our work with children, we can help them understand the behaviour of others. An appropriate selection of texts will help the children get used to the thought that they can rely on their loved ones and that they are not alone with their problems.

A work which has been appropriately selected to suit the age and interests of the reader helps to solve problems which belong to the notion of "taboo", signals a multitude of subjects which are often avoided or, at best, rarely raised in conversations (Kiełtyk-Zaborowska, 2015, p. 82).

Reading books can constitute the first stage to start talking to the child about his or her problems. Based on the experiences and adventures of the hero, the young reader can notice some similarity. The ability to observe and notice variable behaviours while reading should be an indication for the parents to have a further discussion on the text. A conversation about the feelings of the hero, his or her emotions in difficult situations will make it easier to reach the source of the child's problems. Reading books enriches the children's knowledge of the world around them and develops their sensitivity, imagination and empathy.

Children's fears and anxieties appear when they look for new stimuli or places, discover different emotions, change their environment of surroundings. They are also fears resulting from the inability to cope with new phenomena, 
often related to fantasizing or incorrect perception of reality. Family, home environment is one of the most important places of emotional and mental development of children, who need to be helped and provided with the sense of security regardless of their age. We will not avoid problems, which result from the necessity of children to find themselves in a new environment or peer group. Every child needs help and support from their parents, their interest and care (Kiettyk-Zaborowska, 2016, p. 101).

We must keep in mind that each case is different and cooperation with the parents in the fight with difficult behaviours of children is essential, as the family forms the children's closest environment and, at this stage of development, has the greatest influence on them. Therefore, it is important to strive at agreement, even if the parents are initially reluctant and offer resistance. It is worthwhile involving into the cooperation the school counsellor or psychologist.

The role of the teacher is not to tell the parents what to do but rather to offer support and help, to build a relation, which is a long-term process and requires both parties to be involved. The key to proper relations is mutual respect and dialogue aimed at forming the best possible cooperation (Semeniuk, 2019, p. 26-28).

The research was carried out in primary school no. 16 in Piotrków Trybunalski. This school is a municipal institution with approximately 650 students.

The study population consisted of parents of children from grades 1-3. The selection of the research group was random. 53 parents filled questionnaires i.e. 48 women and 3 men. One questionnaire was filled by both parents and in one case the parent's gender was not specified. The majority of the studied parents were between 36-46 years old, 24 people were between 25-35 and two were above 46 years old. Most subjects had higher education - 28 people, 14 had secondary education, 10 - vocational and one had primary education.

In the first question, the respondents were asked if the child showed signs of educational problems. The results were presented in Chart 1.

\section{Chart 1. Does the child display signs of educational problems?}
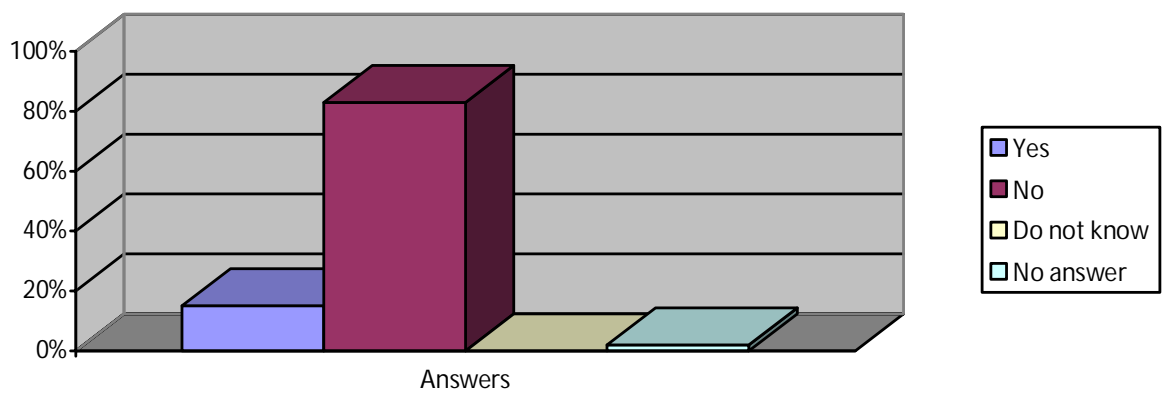

Source: Own research 
Of 53 subjects, $15 \%$ responded affirmatively. $83 \%$ of parents answered that their child did not show signs of educational problems, $2 \%$ did not give any answer. To the second question, which concerned the kind of educational problems, most parents ( $72 \%$ ) did not answer what kind of educational problems were displayed by their child, and only $28 \%$ gave answers.

According to $6 \%$ of parents, the child argues and is disobedient, $4 \%$ indicate that they cannot cope with emotions. The other parents replied that: the child is distracted, does not listen to orders ( $2 \%)$, rebels, does not want to submit ( $2 \%)$, does not want to perform daily activities ( $2 \%)$, is disobedient, has difficulty focusing on lessons ( $2 \%)$, is aggressive ( $2 \%)$, falls into hysteria, is reluctant to do homework (2\%), doesn't express himself well $(2 \%)$, doesn't always follow orders (2\%), gets angry, screams (2\%) (Chart 2). The analysis of the types of upbringing difficulties mentioned by the parents shows that in the majority of the surveyed pupils they exhibit cognitive and emotional disorders as well as personality disorder.

Chart 2. Kinds of educational problems
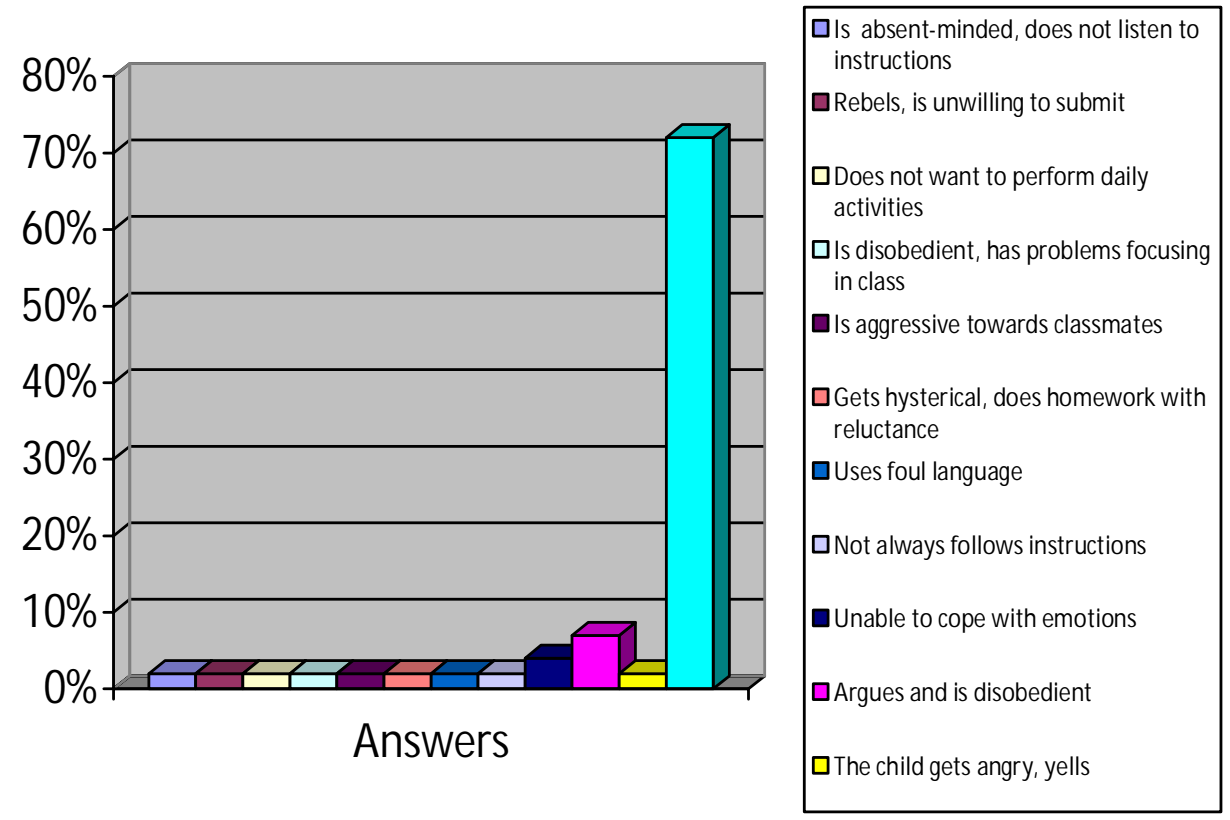

Source: Own research

The next question, concerning the causes of difficult behaviours, was answered by only $42 \%$ of parents, whereas the remaining $58 \%$ did not give any answer. Most parents (19\%) pointed to personality-related causes (e.g. the child gets annoyed quickly, has little self-confidence, gives up quickly, cannot find himself/herself in stressful situations or ones which require hurry, is hypersensitive, has difficult character, is hyperactive). $15 \%$ pointed to situational causes, difficult situation at school and at home (the child copies bad behaviour of his/her elder siblings, often falls ill, is shy, is aggressive). $6 \%$ 
gave biological causes (psychomotor disorders e.g. slow in comparison with the group). $7 \%$ gave other causes (e.g. his/her priority is fun and not learning, bad company). $4 \%$ of the respondents answered 'I don't know', and $58 \%$ did not give any answer (Chart 3).

\section{Chart 3. Causes of difficult behaviours of the child}
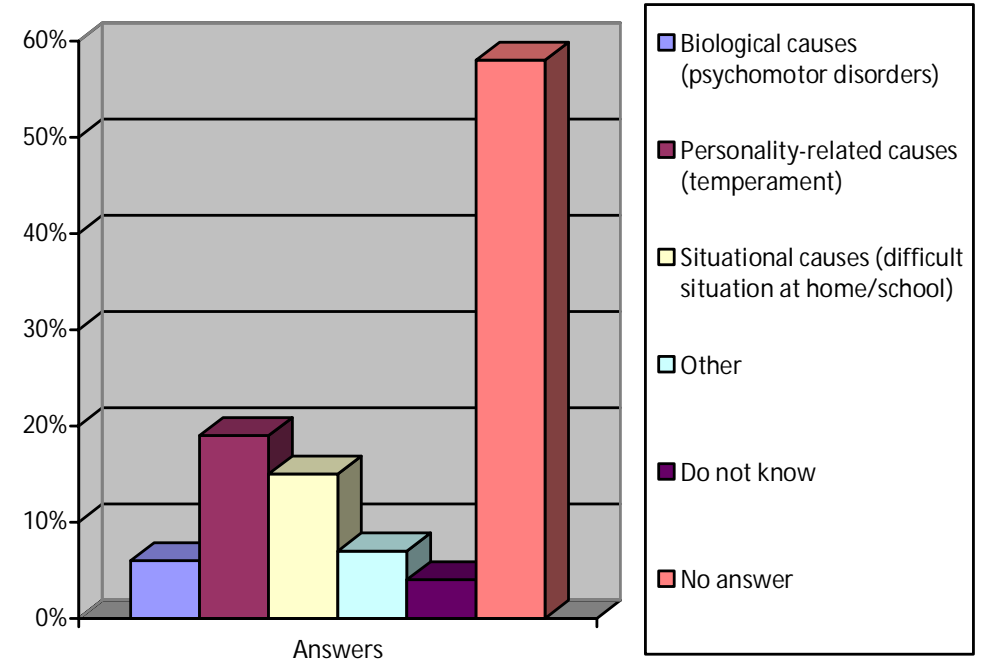

Source: Own research

In question 4, the parents were asked about methods of dealing with the child's difficult behaviours. Of 53 parents, the vast majority (70\%) indicated the tremendous importance of talking to the child and devoting him/her time. The second most frequent answer was using rewards (32\%) and punishments (28\%).

$23 \%$ of parents indicated cooperation with a teacher, $4 \%$ with a psychologist, $6 \%$ with a teacher, $11 \%$ with a psychological and pedagogical counseling center.

$24 \%$ responded that the best method is to introduce a rational daily schedule and discipline. Only $11 \%$ appreciated the importance of bibliotherapy. 1 parent pointed to a visit to a neurologist. $6 \%$ did not give any answer (Chart 4).

The parents are more willing to answer questions about methods of coping with difficult behaviours than questions about the kinds and causes of such behaviours. The results may indicate the parents' reluctance to talk about educational problems of their children or lack of knowledge in this area. M ost frequently, the parents answered questions about care of their children and time devoted to being together with them.

Of the surveyed parents, the majority answered affirmatively that they care about the proper psycho-physical, emotional and social development of the child - $94 \%$. Only $6 \%$ answered that they do it sometimes (Chart 5). 


\section{Chart 4. Methods of coping with difficult behaviours of the child}
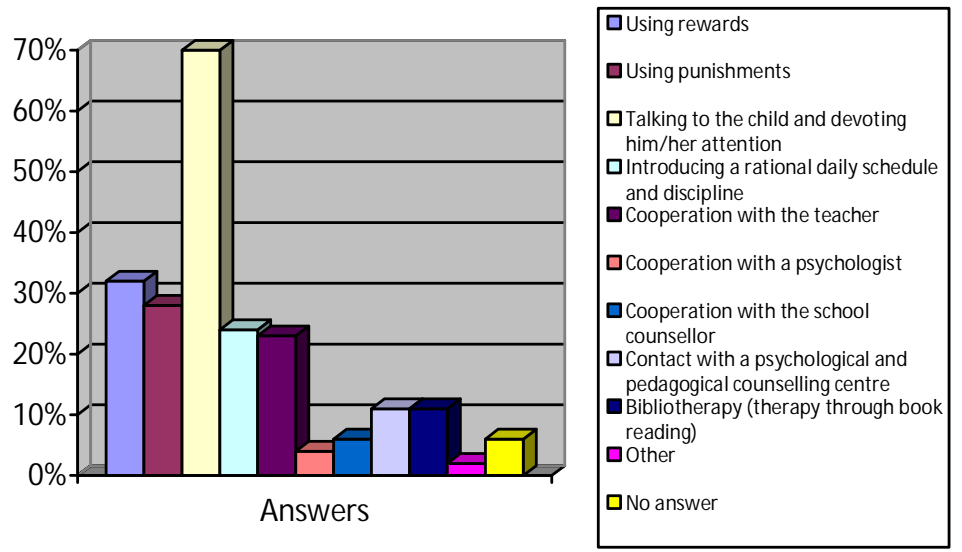

Source: Own research

Chart 5. Do the parents care about the proper psycho-physical, emotional and social development of the child?

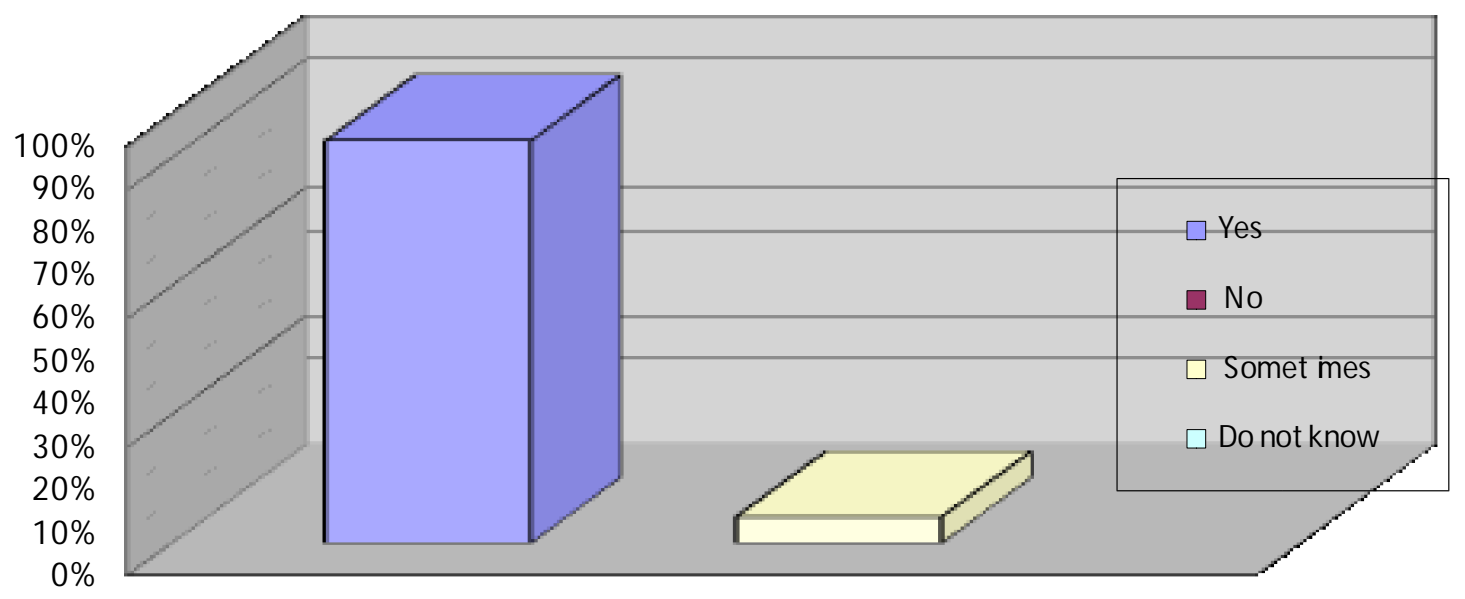

Source: Own research

The next question concerned the methods of caring about the proper development of the child. $98 \%$ of the parents replied to this question and $2 \%$ did not. It follows from the above data that the parents use various methods which influence the proper development of the child. The vast majority of parents pointed to caring about the hygiene - $85 \%$, including the child in the housework $85 \%$, encouraging the child to read books - $77 \%$, care about proper diet - $75 \%$, organising additional activities for the child in accordance with his/her interests $66 \%$, going to the cinema and theatre - $49 \%$, the fewest answers concerned organising the child's participation in sports activities - $41 \%$. In the 'Others' row, 2 $\%$ wrote: bicycle, walks, board games, making rhymes and $2 \%$ noted: contact with the family, talking to each other, trips (Chart 6). 
Chart 6. M ethods of caring about the proper development of the child

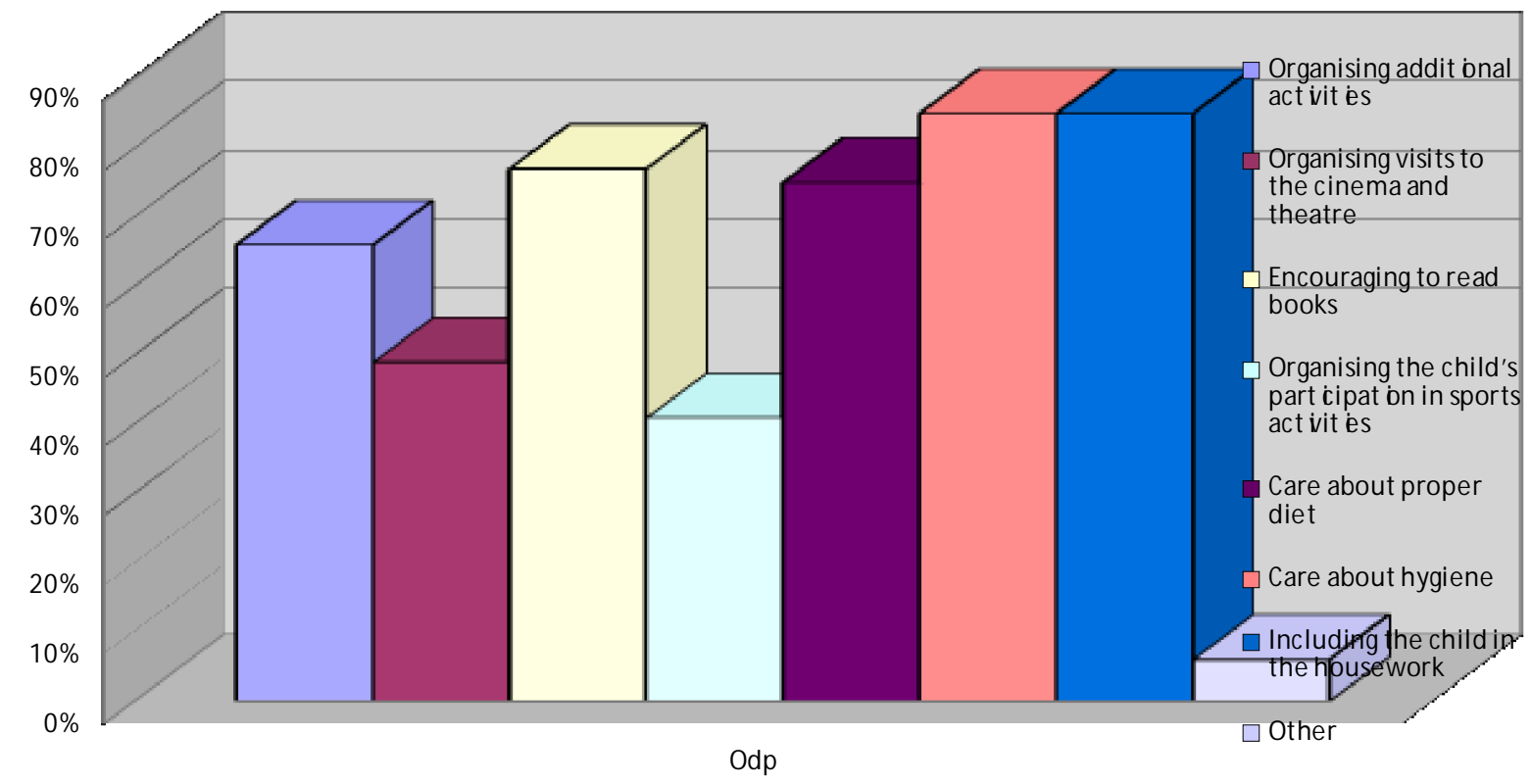

Source: Own research

$98 \%$ of the parents maintain systematic contacts with teachers and the child's class tutor. Only $2 \%$ do not maintain such contacts (Chart 7).

Chart 7. Maintaining systematic contacts of the parent with the teachers and class tutor of the child

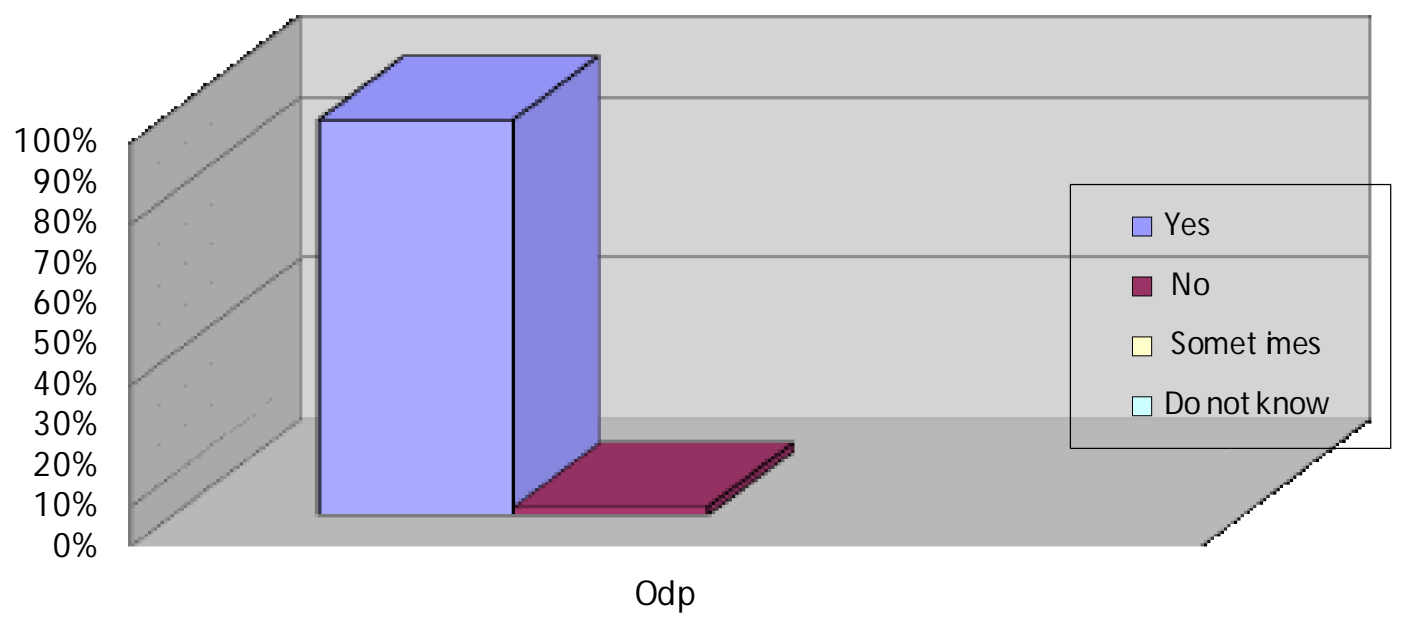

Source: Own research

The majority of parents (53\%) contact the class tutor once a month, which roughly corresponds to the frequency of parent meetings or consultations organised by the school. $21 \%$ contact once a week, $9 \%$ - twice a month and $6 \%$ - twice a year. $8 \%$ pointed other frequency. $3 \%$ of parents did not answer (Chart 8). 


\section{Chart 8. Frequency of parents' meetings with the class tutor}

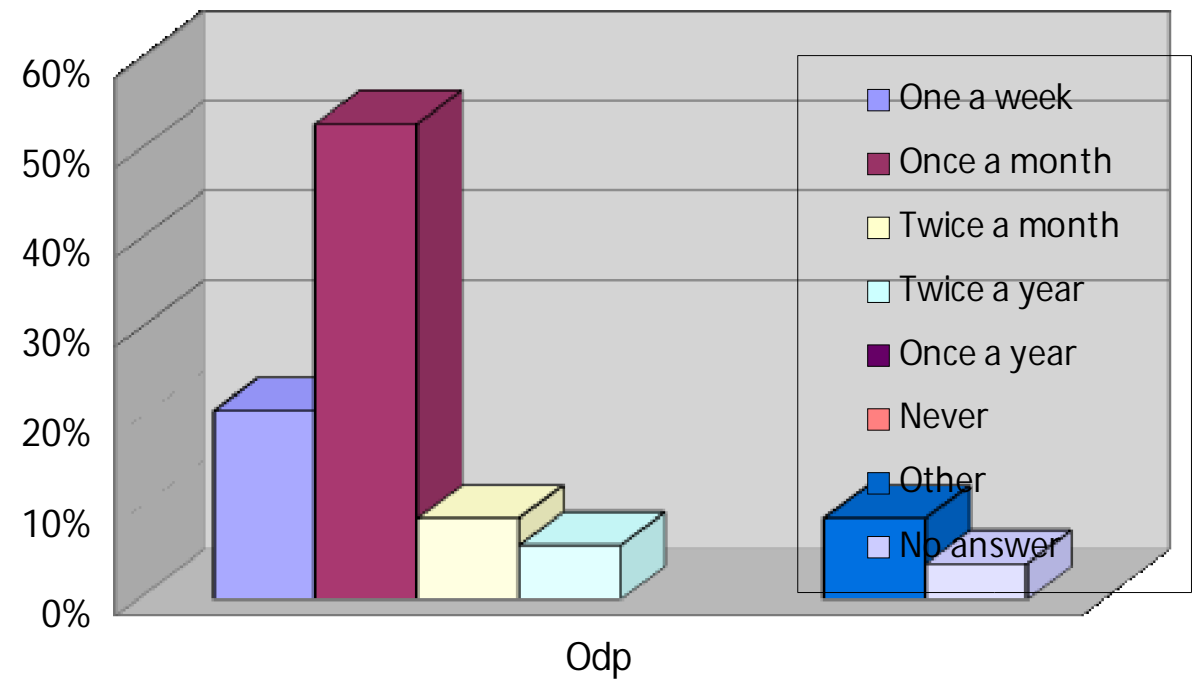

Source: Own research

The majority of parents (36\%) confirmed that they receive assistance in overcoming problems in bringing up the child. $2 \%$ replied that teachers, school counsellor and the headmaster all provide assistance in overcoming educational problems. $26 \%$ of the parents replied that there is no such need, 4 $\%$ of the parents do not know if the school: teachers, headmaster and school counsellor assist in overcoming the child's educational difficulties, $6 \%$ claimed that if there was a need for receiving assistance, they might use it. $2 \%$ believe that the parent's role is to bring up and the school's task is to teach. $24 \%$ of the parents did not give any answer to this question (Chart 9).

\section{Chart 9. Assistance for the parents from the school in overcoming difficulties in educating the child}

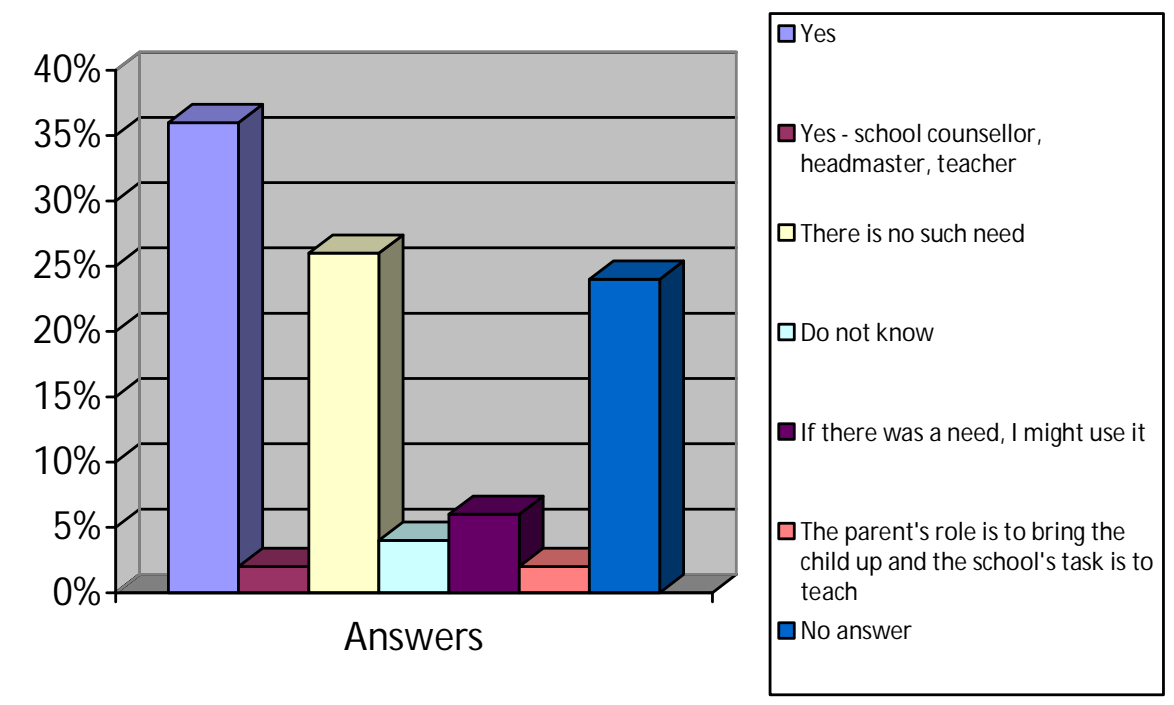

Source: Own research 
Of all the answers to the question about methods which the school uses to assist parents in overcoming educational problems, the majority (32 \%) indicated the fact that the school organises additional extracurricular activities and cooperates with the teacher or psychologist. Such forms were also listed as: maintaining contacts between teachers and parents and organising workshops for parents (7\%), conversations with the parents (4\%), upbringing (2\%), communication with the parents, patience, understanding without accusation (2\%), equal treatment of children (2\%), using clear principles of discipline (2\%), organising interesting projects for children (2\%).

$2 \%$ decided that there is no need for the school to assist parents, $2 \%$ do not know how the school helps parents in overcoming educational problems. $43 \%$ of the parents did not give any answer (Chart 10).

\section{Chart 10. Methods the school uses to assist parents in overcoming educational problems}

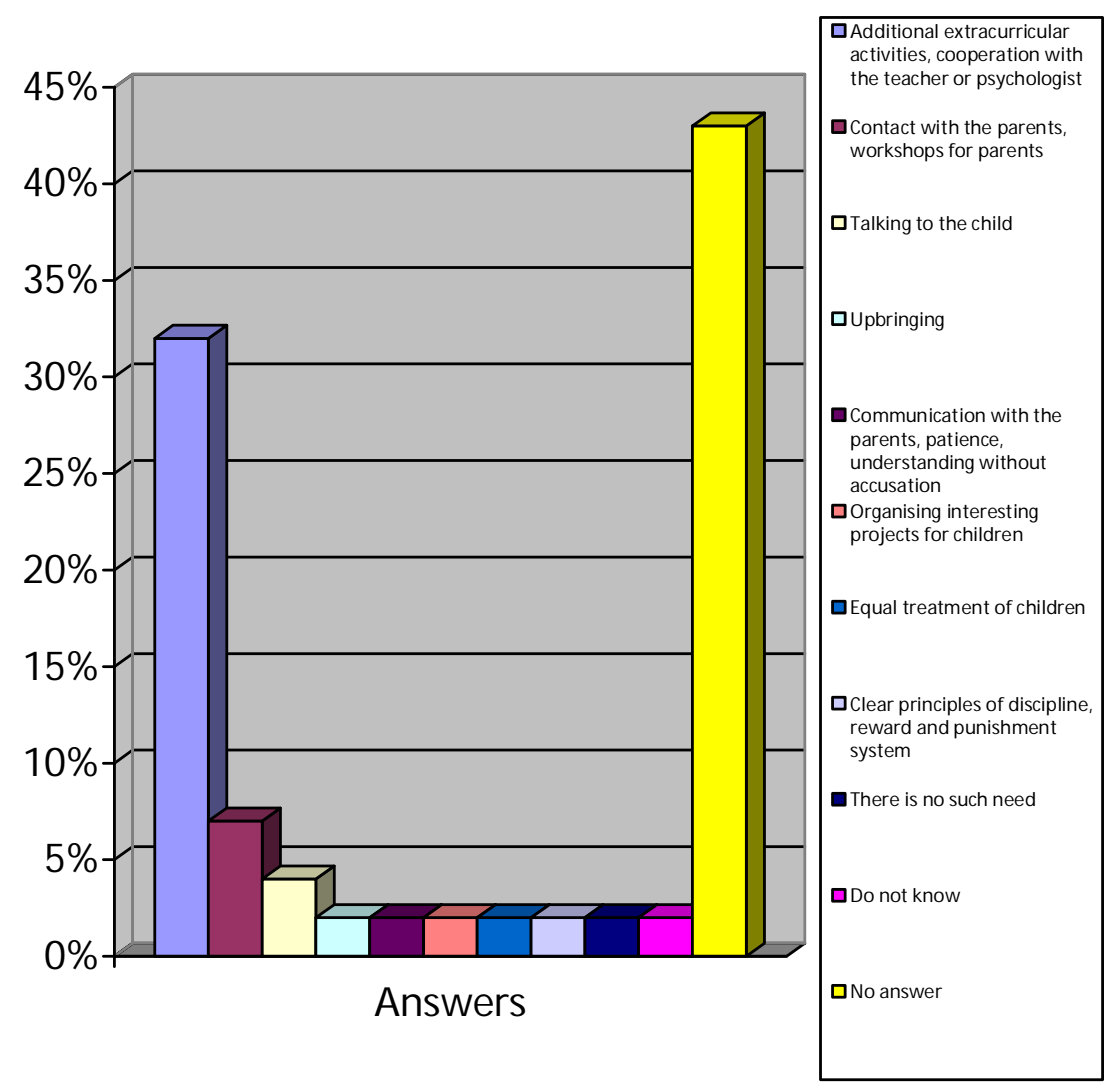

Source: Own research

The survey results indicate that only $26 \%$ of the parents are satisfied with the cooperation with the school in the field of solving educational problems. $9 \%$ of the parents replied that they have no problems with the child, and $9 \%$ are not satisfied with the cooperation with the school. $2 \%$ do not see problems in the cooperation with the school. $2 \%$ indicate the need for proper communication. 
$2 \%$ stated that the problems reported by the child are not fully heard.

Some of the respondents were undecided as to whether they know if they are satisfied with the cooperation with the school (4\%), difficult to say - $4 \%$ replied so. Most of the respondents (42\%) did not give any answer (Chart 11).

\section{Chart 11. The degree of parent's satisfaction with the cooperation with the school in the field of solving problems related to educating the child}

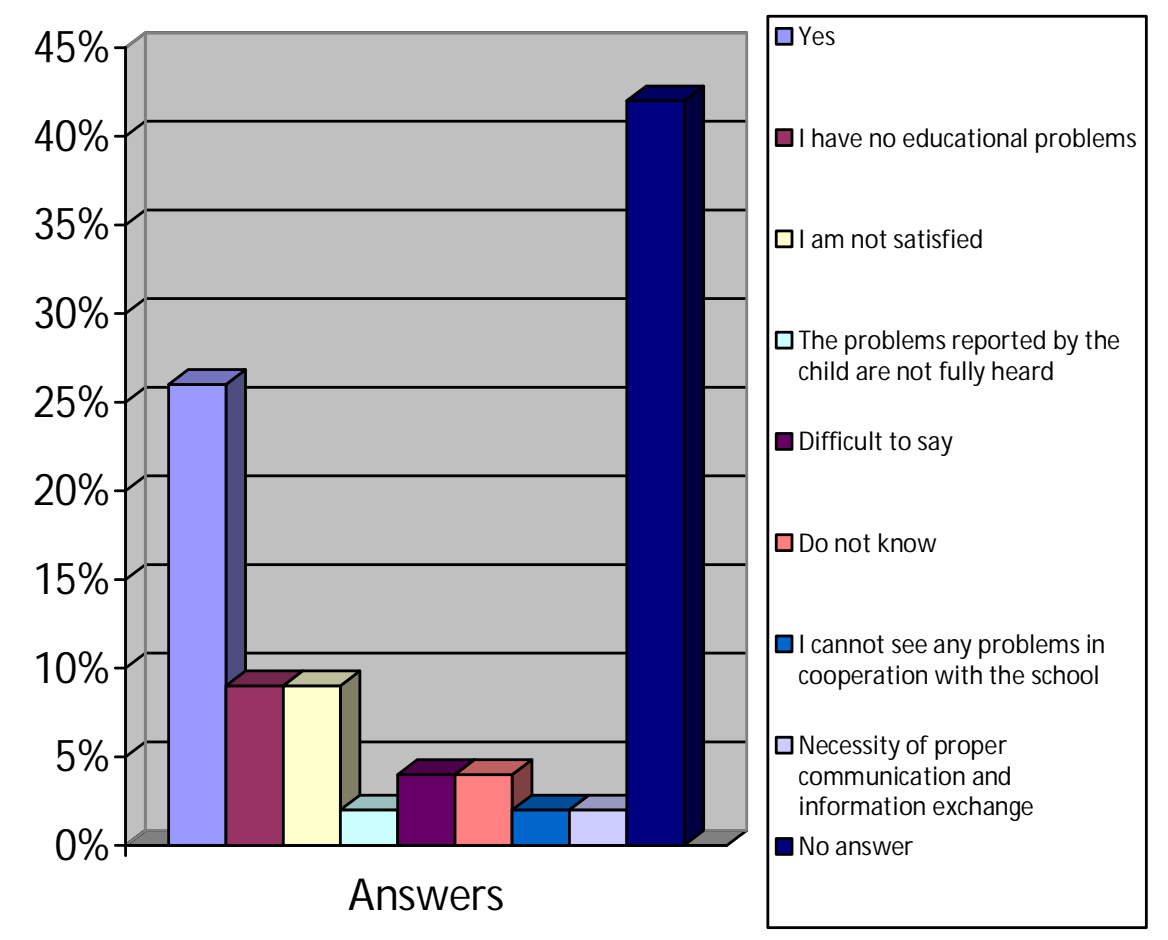

Source: Own research

In the question concerning methods of preventing educational problems, $62 \%$ of the parents believe that it is possible to prevent the problems and list various methods of overcoming them such as: talking to the child, observation, good example or spending free time together. The parents think that it depends on them whether the children will overcome educational problems, on their attitude and consistency in action. They also notice a great role of the school, i.e. the teachers and school counsellor, who can also be helpful. They point to the necessity to cooperate with the school, to use the advice of a specialist and training courses for parents. $2 \%$ of the parents answered negatively, $2 \%$ do not see any problem, $2 \%$ have no opinion, $2 \%$ believe that nowadays prevention of problems is very difficult. $30 \%$ did not give any answer to this question (Chart 12). 


\section{Chart 12. Methods of preventing educational problems}

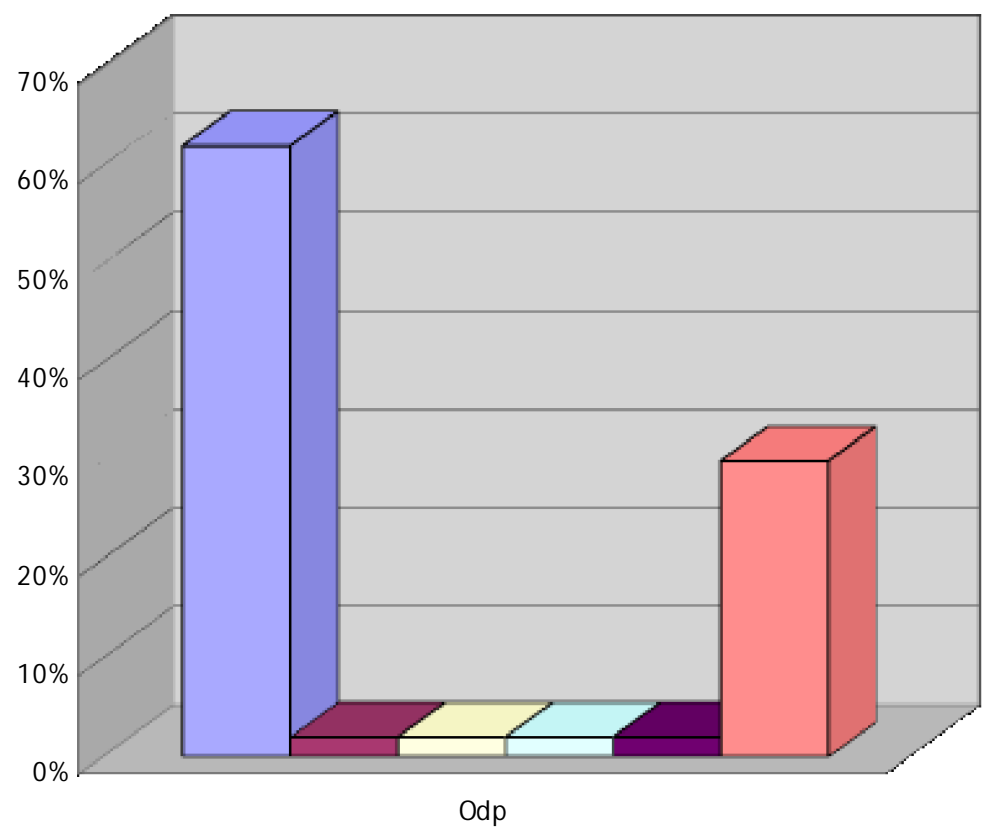

$\square$ Talking to the child, consistency in enforcing instruct ons and spending free $t$ ime toge-

ther, using advice from specialists

$\square$ Problems cannot be prevented

$\square$ I can see no problem

$\square$ Nowadays prevent on of problems is very

dif tult

No opinion

$\square$ No answer

Source: Own research

\section{Summary of results}

Analysis of research results concerning the role of parents and cooperation with the school in preventing and overcoming educational problems allowed the following conclusions to be formulated:

The vast majority of parents state that their children do not show signs of any educational problems ( $83 \%$ ). When asked about the type of educational difficulties, only $28 \%$ of the respondents mention many different difficulties they have observed.

In regard to causes of the child's difficult behaviours, most answers indicated personality-related causes (19\%), then situational causes (15\%), and the fewest: biological causes (5,6\%).

The parents point to a large variety of methods used for dealing with difficult behaviours, assigning the greatest importance to talking with the child and devoting him or her attention (70\%), consistence in enforcing the instructions and spending free time together.

Parents are more likely to answer questions about how they deal with difficult child behaviors than to questions about the types and causes of difficult behavior of children. The results of the research may indicate a reluctance of parents to talk about the educational difficulties of children or a lack of knowledge in this area. Parents were eager to answer questions about childcare and the time spent with the child. 
The parents provide their children with loving care, which is manifested in their care about the psycho-physical, emotional and social development, including a diversity of forms of spending free time, care about hygiene (85\%), proper nourishment (75\%).

The majority of parents care about providing the child with good conditions for learning and working at home (75\%).

The parents are definitely interested in the child's school affairs, the maintain systematic contacts with the teachers and class tutor (98\%). However, $26 \%$ point out that they see no need for the school to assist them in overcoming the problems with bringing up the child.

Among the methods listed for the school to help in overcoming educational problems, the largest number of parents (45\%) indicated additional extracurricular activities for children, cooperation with the teacher or psychologist and workshops for parents. However, only $26 \%$ of the parents are satisfied with cooperation with the school.

The majority of parents (62\%) believe that it is possible to prevent educational problems and they know how to do it. They think it is on the cooperation between the parents and the school that the success in overcoming educational problems relies, as well as on their attitude and consistency in action.

Conclusions. The possibility of obtaining assistance from the school, with the parent's open attitude towards the noticed problem, determines the effectiveness of the undertaken actions.

This is why it is very important to select appropriate forms of assistance to the parents and to provide it in a professional manner so that the parents can become partners of teachers and beneficiaries of this cooperation ( $M$ endel, 2009, p. 200; Mendel, 2000, p. 155; Epstein, 1995, p. 45). Educational partnership in the understanding of Alistair Macbeth is a relationship connecting parents and teachers of their children, which is a mixture of autonomy and interdependence, and the value is a common goal and cooperation leading to it (M acbeth, 1995, p. 55).

Increased awareness of the parents, their ability to observe and notice alarming behaviours of the child should direct their attention to the possibility of starting a cooperation with the school, class tutor, counsellor or psychologist (Zamecka-Zalas, 2011, p. 141; Dzierzgowska, 2000, p. 200). Better learning results, and thus better education of the child, depend on good cooperation between school and parents (Dusi, 2012, p. 33). 
The cooperation between the two environments: the family and the school must be oriented at support, mutual understanding and the parents' active participation in the undertaken actions. Changing the parents' activeness means changing the principles of cooperation and the entire activity of the school. The educational partnership at school is about creating a space for cooperation, whose aim is the good of the child.

\section{REFERENCES}

Babiuch, M. (2002). Jak współpracować z rodzicami „trudnych" uczniów? Warszawa: WSiP. Bałachowicz, J. (2009). Style działań edukacyjnych nauczycieli klas poczqtkowych. Między uprzedmiotowieniem a podmiotowościq. Warszawa: Wydawnictwo WSP TWP.

Dusi, P. (2012). The Family School Relationships in Europe: A. Research Review. CEP Journal, 2. Dzierzgowska, I. (2000). Rodzice w szkole. Warszawa: Wydawnictwo CODN.

Epstein, J. E. (1995). School/Family/ Community Partnerships. Caring for the Children We Share. Phi Delta Kappan: May.

Havers, N. (1978). Erziehungsschwierigkeiten in der Schule. Klassifikation, Häufigkeit, Ursachen und pädagogischtherapeutische M assnahmen. Beltz: Weinheim.

Hillenbrand, C. (2007). Pedagogika zaburzeń zachowania, przeł. E. Cieślik. Gdańsk: GWP.

Kiełtyk-Zaborowska, I. (2015). Biblioterapia wobec tematów tabu na podstawie powieści

Luciany Martini pt. Kolor wiatru. In J. Juszczyk-Rygałło (Ed.), Wielowymiarowość współczesnej edukacji dziecka., Częstochowa: Wydawnictwo im. Stanisława Podobińskiego Akademii im. Jana Długosza w Częstochowie.

Kiełtyk-Zaborowska, I. (2016). Pokonywanie dziecięcych lęków, czyli biblioterapia w domowym zaciszu. In J. Bujak-Lechowicz (Ed.), Kulturowy obraz bezsenności, (pół)snu i marzeń sennych. Szczecin: Wydawca wolumina.pl Daniel Krzanowski.

Kołakowski, A. (2014). Zaburzenia zachowania u dzieci. Teoria i praktyka. Sopot: GWP. Leśniewska, K. (2019). Współpraca z rodzicami. Co robić, żeby się udało? Wczesna Edukacja, 3. Macbeth, A. (1995). Partnership Between Parents and Teachers in Education. In A. Macbeth, D. M cCreath, J. Aitchison (Eds.), Collaborate or Compete? Educational Partnerships in a Market Economy. London-Washington.

Mendel, M. (2009). Nauczyciel z uczniem, rodzicami i lokalną społecznością. Koncepcje partnerstwa edukacyjnego. In D. Klus-Stańska, M. Szczepska-Pustkowska (Eds.), Pedagogika wczesnoszkolna - dyskursy, problemy, rozwiqzania. Warszawa: WaiP.

Mendel, M. (2000). Partnerstwo rodziny, szkoły i gminy. Toruń: Wydawnictwo Adam Marszałek.

Nadolska, A. (2013). Praca z trudnym uczniem. Problemy Opiekuńczo - Wychowawcze, 8.

Oleksa, K. (2016). Trudne zachowania uczniów. Jak radzić sobie z klasowymi łobuzami. życie Szkoty, 4.

Sakowicz-Boboryko, A. (2004). Trudny uczeń, in: Encyklopedia pedagogiczna XXI wieku. Warszawa: Wydawnictwo Akademickie "Żak”.

Semeniuk, A. (2019). 6 kroków do zbudowania dobrej relacji z rodzice. życie Szkoły, 7.

Skupień, S., Kowal, S. (2019). Tutoring rodzinny jako przykład współpracy nauczycieli z rodzicami. Wychowawca, 10.

Spionek, H. (1985). Zaburzenia rozw oju uczniów a niepowodzenia szkolne. Warszawa: PWN. Szymański, M. J. (2013). Socjologa edukacji. Zarys problematyki. Kraków: Wydawnictwo Impuls. 
Zamecka-Zalas, O. (2014). Rodzina i szkoła środowiskiem wsparcia dla dziecka. In M. Cywińska (Ed.), Problemy współczesnego dziecka. Wybrane aspekty. Poznań: Wydawnictwo Naukowe UAM .

Zamecka-Zalas, O. (2011). Trójpodmiotowość w edukacji wczesnoszkolnej - koncepcje partnerstwa edukacyjnego. In J. Szempruch, M. Kwaśniewskiej, A. Szplit (Ed.), Podmiotowość w edukacji - wymiary i konteksty. Kielce: Wydawnictwo LIBRON.

\section{PEЗЮME}

Замецкая-Залас Ольга, Келтык-Заборовская Изабела. Роль родителей и сотрудничество со школой в предотвращении и преодолении образовательных проблем.

В статье представлено эмпирическое исследование роли родителей и их сотрудничества со школой в предотвращении и преодолении образовательных трудностей. Для эфрективного обучения недостаточно быть компетентным и дружелюбным по отношению к ученикам. Образовательные трудности являются результатом многих факторов, поэтому учитель имеет ограниченные возможности для решения таких задач. Даже самые совершенные методы обучения, используемые учителем, который работает в одиночестве, или родителями, действующими в одиночку, не будут эфррективными. Они должны сотрудничать и поддерживать друг друга, чтобы избежать трудностей. Вот почему необходимо сотрудничество родителей со школой, чтобы справиться с трудным поведением учеников.

Ключевые слова: сотрудничество родителей со школой, образовательные трудности младших школьников.

\section{АНОТАЦІЯ}

Замецька-Залас Ольга, Келтик-Заборовська Ізабела. Роль батьків і співпраця зі школою в запобіганні й подоланні освітніх проблем.

У статті представлено емпіричне дослідження ролі батьків та їх співпраці зі школою в запобіганні й подоланні освітніх труднощів. Для ефективного навчання недостатньо бути компетентним і доброзичливим по відношенню до учнів. Освітні труднощі $\epsilon$ результатом багатьох факторів, тому вчитель має обмежені можливості для вирішення таких завдань. Навіть найдосконаліші методи навчання, використовувані вчителем, який працює на самоті, або батьками, які діють поодинці, не будуть ефективними. Вони повинні співпрацювати й підтримувати один одного, щоб уникнути труднощів. Ось чому необхідна співпраця батьків зі школою, щоб упоратися з важкою поведінкою учнів.

Можливість отримати допомогу від школи, з відкритим ставленням батьків до поміченої проблеми, визначає ефрективність вжитих дій. Ось чому дуже важливо вибрати відповідні форми допомоги батькам і надати ії профресійно, щоб батьки могли стати партнерами вчителів та бенефіціарами чієї співпраці.

Підвищена обізнаність батьків, їх здатність спостерігати і помічати тривожну поведінку дитини повинна спрямовувати їх увагу на можливість початку співпраці зі школою, класним керівником, консультантом або психологом. Кращі результати навчання, а отже і краща освіта дитини, залежать від ефективної співпраці школи та батьків. 
Співпраця між двома середовищами - сім'єю та школою - має бути зорієнтована на підтримку, взаєморозуміння й активну участь батьків у в освітньому процесі. Зміна активності батьків означає зміну принципів співпраці та всієї діяльності школи. Освітнє партнерство в школі полягає у створенні простору для співпраці, метою якої є добробут дитини.

Ключові слова: співпраця батьків зі школою, освітні труднощі молодших школярів.

UDC 378:61].091.39-027.15-025.13

\section{Alla Kulichenko \\ Zaporizhzhia State M edical University \\ ORCID ID 0000-0003-1469-3816 \\ DOI 10.24139/2312-5993/2020.05-06/178-190 \\ THEORETICAL ASPECTS OF INNOVATION MODELS AND THEIR PRACTICAL IM PLEM ENTATION IN M ODERN M EDICAL EDUCATION}

The article deals with theoretical aspects of innovation models and their implementation in modern medical education. The author focuses on the first innovation model, proposed by J. Schumpeter during the first half of the $20^{\text {th }}$ century. This model considers the so-called "triad" in the innovation process, namely invention, innovation, diffusion. Besides, in this context, J. Schumpeter described the concept of "creative destruction". As for the last quarter of the $20^{\text {th }}$ century, there were such innovation models as (i) induced innovation model, (ii) evolutionary models, and (iii) models that characterize the way of innovation. The end of the $20^{\text {th }}$ century represented the development of the model of national innovation systems and the model of technological innovation systems.

Key words innovation, innovation models, innovation process, research and development, linear model of innovation, induced innovation model, evolutionary models, model of national innovation systems, model of technological innovation systems, medical education.

Introduction. During the $20^{\text {th }}$ century, medical education has undergone many changes. They are mostly related to innovations in teaching, research, and management of higher education institutions. P. González-Floresa and L. Luna argue that "some innovations are still being implemented and have even been adapted to other contexts (i.e. problem-based learning), while others have been discarded" (González-Floresa \& Luna, 2019). The matter is that the authorities of each country chose the appropriate development strategy for education within the certain innovation model.

Analysis of relevant research. The issue of innovation models is applicable in the economy, management, and technology. K. Arrow, C. Freeman, B. Lundvall, R. Nelson, C. Perez, J. Schumpeter, R. Solow, S. Winter, and others dedicated their studies to this point in different years of the $20^{\text {th }}$ 